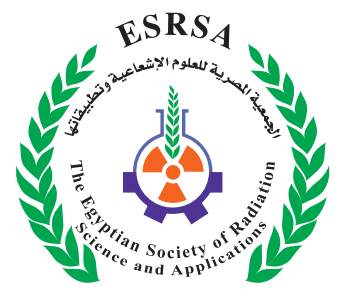

J. Nucl. Tech. Appl. Sci., Vol. 7, PP. 197 : 208 (2019)

\title{
Enhancing skin regeneration in gamma irradiated mice by Low-level laser Therapy
}

Yousri, R.M. ${ }^{1}$; Shokeir H.A. ${ }^{2}$; El Batanouny M.H. ${ }^{3}$, Mahfouz, S. ${ }^{3}$, and Salem E.S. ${ }^{2}$

Received: 20/05/2019

Accepted: 27/08/2019

E-mail: raafatyousri@hotmail.com

\section{KEYWORDS}

Gamma-irradiation, mice, skin, $\mathrm{He}-\mathrm{Ne}$

laser.

\section{ABSTRACT}

Background: The skin is considered to be a radiosensitive organ. Low-level laser therapy (LLLT) known as photobiomodulation is a growing technology used to treat multitude of conditions that require stimulation of the healing process. Aim of the work: The present work was conducted to study the possible biostimulatory effects of LLLT on the skin of gamma irradiated mice. Materials and methods: 264female mice were used in the present experiments were divided into 6 groups: Group (1): Non irradiated control group. Group (2): Laser irradiated group. Group (3.1): One shot gamma irradiated group. Group (3.2): One shot + laser irradiated group. Group (4.1): Cumulative gamma irradiated group. Group (4.2): Cumulative + laser irradiated group. Exposure of the animals to gamma rays was performed using a cesium-137 source. Two modes of exposure were used, a shot modality where the mice were irradiated with a single sub lethal dose of $5 \mathrm{~Gy}$. While in the other mode, the same dose was given in fractionated daily installations of $1 \mathrm{~Gy}$. Treatment of mice with laser was carried out using a computerized scanner emitting He-Ne (CW) at a wavelength of $632.8 \mathrm{~nm}$. The fluence was $5 \mathrm{~J} / \mathrm{cm}^{2}$. Histopathological (HP) assessment of skin biopsies derived from the experimental mice was done immediately after each sacrification.Conclusion: LLL therapy accelerates skin regeneration post exposure to ionizing radiation in both shot and cumulative mode. Our conclusions also highlight the biostimulatory effect of He-Ne LLL on hair follicles.

1. National Center for Radiation Research and Technology (NCRRT), Atomic Energy Authority (AEA), Cairo, Egypt.

2. National Instituted of Laser Enhanced Sciences (NILES) Cairo University.

3. Faculty of Medicine, Cairo University 


\section{INTRODUCTION}

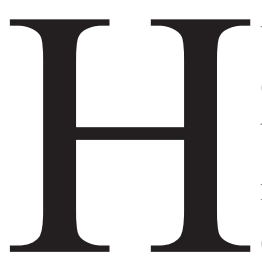

umans are exposed to low levels of ionizing radiation on a daily basis due to the naturally occurring background radiation, medical diagnostic procedures as well as radiation occupational exposures. There are also plausible scenarios in which large segments of the population could be exposed to both low and high doses of radiation due to terrorist acts or nuclear accidents (Hengel et al., 2014).

Because of their great penetrating ability, $\gamma$ - rays are by far the most dangerous type of radiation when they come from a source outside the body (Merrifield and Kovalchuk, 2013).

Isoiret et al., (2005) stated that radio-sensitivity means the relative vulnerability of different cells to the damage induced by ionizing radiation (I.R). They attributed variation in radio-sensitivity to normal turnover time of the cells and the ability of the tissue to repair damaged cells. Radio dermatitis is a significant side effect of ionizing radiation exposure (Singh et al., 2016).

Radio sensitivity is the probability of a cell, tissue, or organ suffering an effect per unit dose of radiation. Radio sensitivity is highest in cells which are highly mitotic or undifferentiated. For this reason the basal epidermis, bone marrow, thymus, gonads, and lens cells are highly radiosensitive. Muscle, bones, and nervous system tissues have relative low radio sensitivity (Goodman, 2010).

Light absorption is dependent on wavelength and the main tissue chromospheres (haemoglobin and melanin) strongly absorb wave lengths shorter than $600 \mathrm{~nm}$. For these reasons, there is a therapeutic window in the optical spectral range of red and near infrared, wherein the efficiency of light penetration in the tissue is maximal (Chaves et al., 20014). Accelerating skin wound healing was verified to be one of the most successful applicability of low-level laser therapy (LLLT) Alves et al. (2014) and Rashidi et al. (2015) documented that LLLT shows high therapeutic efficacy for different chronic wounds particularly skin wounds, diabetic ulcers and necrotic wounds.

The aim of the present study was to investigate the bioregenerative and repair capacity of laser therapy on the skinof miceexposed to $\gamma$-radiation.

\section{MATERIALS AND METHODS}

\section{Experimental Animals:}

Two hundred and sixity four (264) mice of the same colony aged approximately four months and weighing $25 \pm 5 \mathrm{~g}$, were used in the present study. The mice were kept under good ventilation and illumination systems and were maintained on a well balanced standard diet and free water supply.

\section{Gamma-Irradiation Processing:}

The source of ionizing radiation was a Gamma cell-40(Caesium-137). Irradiation source belongs to the National Centre for Radiation Research and Technology (NCRRT), Atomic Energy Authority(AEA). The irradiation tray has ventilation holes on its side, which align with the ventilation parts through the main shield of the unit to ensure animals aeration. Two modes of irradiation exposure were used; a shot modality where the mice were exposed to a single sub lethal dose of $5 \mathrm{~Gy}$. In the other mode, the sub lethal dose was given in fractionated daily installations of 1 Gy (EI Batanouny et al., 2019).

\section{Non-ionizing Laser Processing:}

The laser irradiation unit is a computerized scanner emitting continuous wave $(\mathrm{CW})$ helium-neon with wavelength $632.8 \mathrm{~nm}$ and the fluence is $5 \mathrm{~J} /$ $\mathrm{cm}^{2}$. The unit is a class (4) laser with output power of $(10 \mathrm{mw})$. The irradiated animals were placed 30 $\mathrm{cm}$ from the laser source. This unit belongs to the National Institute of Laser Enhanced Sciences (NILES), Cairo University.

Subcutaneous injection of ketamine was followed by laser irradiation transcutaneously to the 
shaved epigastric surface of the mice abdomen.Uniform laser exposure was maintained by the use of an attached scanner.Laser treatment started immediately after the exposure to $5 \mathrm{~Gy}$ gamma radiation which were given either by the shot or the cummulative mode and was repeated every other day during a four weeks interval.

It is interesting to indicate and justify that the study protocol and experimental procedures were carried out according to the international guidelines for animal experiments approved by the National Institute of Health (NH No. 85:23, revised 1996) and in compliance with the regulations of the National Center for Radiation Research and Technology (NCRRT), Atomic Energy Authority (AEA), Egypt. The experimental design of the study is illustrated in the following chart.

It is also valuable to indicate that at the end of each week the number of sacrificed mice was increased to be 6 instead of 3 mice in order to collect enough amount of blood serum sufficent to carry out the biochemical analysis .

Excised skin from all mice was fixed in $10 \%$ neutralized neutral buffered formalin for 48 hours, then transferred to $70 \%$ ethyl alcohol, processed and embedded in paraffin blocks. Serial sections of 5-6 um thickness were stained by hematoxylin and eosin stains (H\&E) and Masson trichrome (MT) (Bancroft $\boldsymbol{e t}$ al., 1996) and then examined histologically through the electric light microscope (Olympus BX51 T- 32000).

A Flow Chart of the Animal Groups

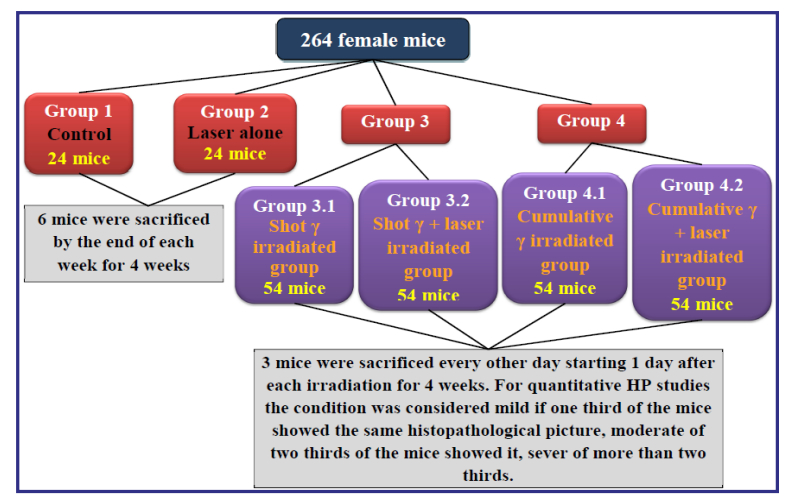

\section{RESULTS}

\section{Histopathological (HP) assessment of the skin \\ Group (1): Non-irradiated control group:}

The stratified squamous keratinized epithelium of the epidermis was of normal thickness. The outer layer of the epidermis (Stratum corneum) was shown as a multicellular membrane of dried, flattened keratinocytes. (Fig.1).

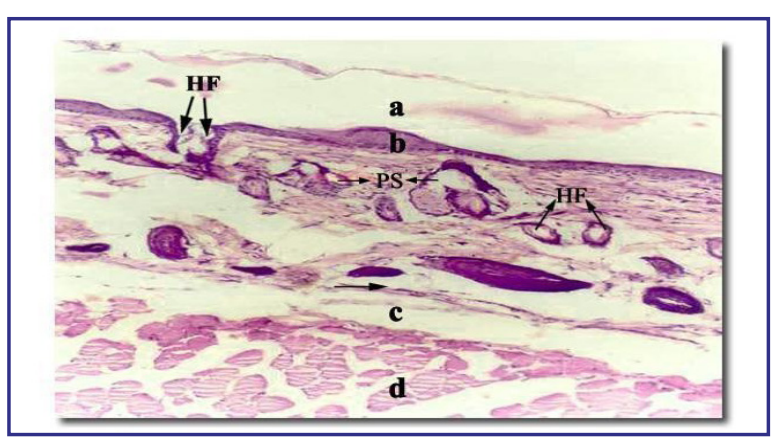

Fig. (1): Light micrograph of a section in the skin of a mouse in Group 1 showing normal skin.
a: stratum corneum
b: granular layer
c: dermis
HF: hair follicles
$\mathrm{d}$ : sub cutaneous tissue
PS: pilosebaceous

(HE X400)

The granular layer of the epidermis was found to be formed of deeply basophilic cells with the basal layer being formed of germinative cells, which were metabolically active and showed many mitotic figures (Fig. 1, 2). The connective tissue of the dermis was seen to be formed of bundles of loose collagenous fibers and the epidermal appendages which include the hair follicles and pilosebaceous units (Fig. $1,2)$.

The subcutaneous tissue included predominantly fat cells and also a network of arteries, veins and lymphatics which at intervals penetrate into the dermis (Fig. 1).

\section{Group (2): Non ionizing radiation (laser) group:}

HP of skin biopsies showed that He-Ne laser induced no abnormal changes in the skin that could be detected by the ordinary microscope using both HE stain and M T stain throughout the whole experimental period (Fig. 3). 


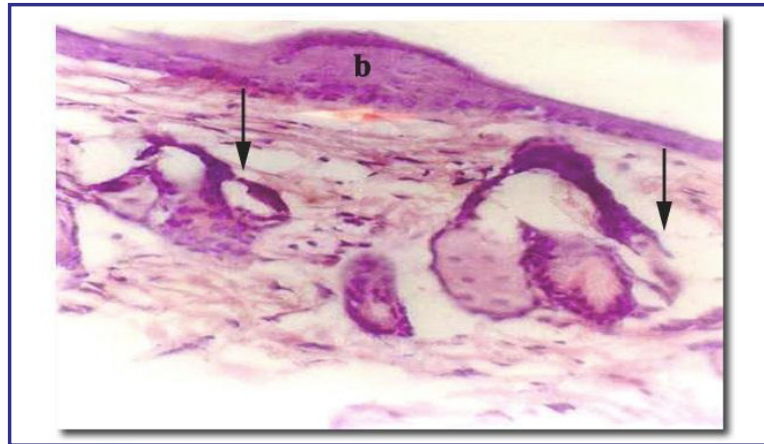

Fig. (2): Light micrograph of a section in the skin of a mouse in Group 1 showing normal pilosebaceous (hair follicles and sebaceous glands) (arrows).
a: stratum corneum
b: granular layer
c: dermis
d: sub cutaneous tissue
HF: hair follicles
(HE X400)

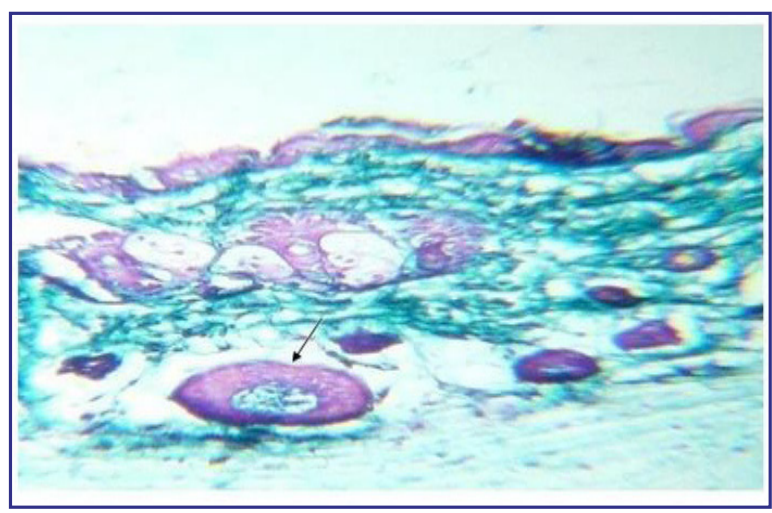

Fig. (3): Light micrograph of a section in the skin of a mouse in Group 2 showing normal pilosebaceous (arrows). (MT X400)

\section{Group (3.1): (Shot group) Table (1)}

\section{One day post irradiation up to the end of the $1^{\text {th }}$ week:}

Gradual progressive desquamation (total loss of the epidermis) was observed and associated with loss of rete ridges as well as variable degrees of damage of pilosebaceous units. Dense diffuse dermal thickening by accumulating pink homogenous dense material could also be seen. By the end of the $1^{\text {st }}$ week, beside severe desquamation and loss of rete ridges and sebaceous glands, remnants of destroyed hair follicles were seen. Dermal thickening by diffuse dense tissue became more evident at this stage (Fig. 4\&5).

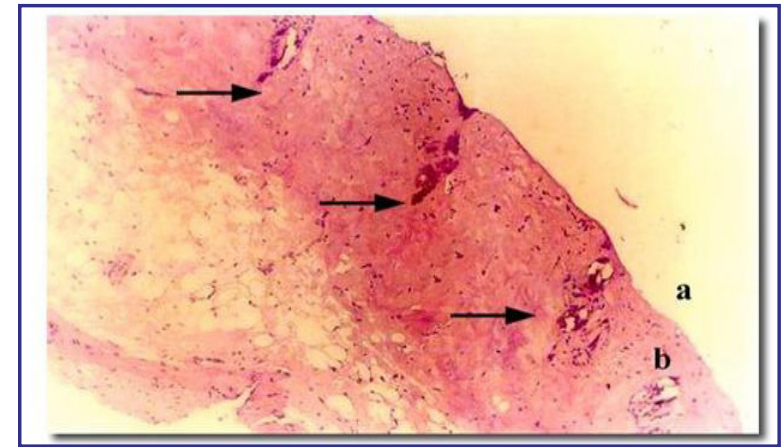

Fig. (4): Light micrograph of a section in the skin of a mouse in Group 3.1 showing:

a: total loss of the epidermis

b: dermal thickening of dense tissue

c: comenents of pilosebaceous (arrows)

(HE X400)

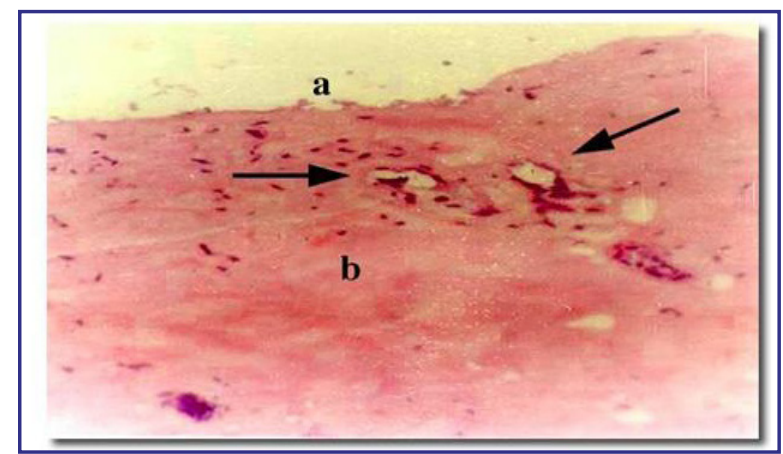

Fig. (5): Light micrograph of a section in the skin of a mouse in Group 3.1 showing:

a: absent epidermis with loss of rete ridges.

$\mathrm{b}$ : thick dense dermis with absence of well-formed hair follicles (arrows)

(HE X400)

\section{During the second and the third week}

The HP changes were the same as that observed by the end of the $1^{\text {st }}$ week with complete hair follicle loss and increased dermal thickening (Figs. 6).

\section{During the fourth week:}

Early signs of spontaneous healing included reappearance of rete ridges but they were still flat. The newly formed epidermis showed, marked thinning. As spontaneous healing gradually progressed, the stratum corneum and granular layer were seen to regrow and regain normal thickness in some areas and even becoming thicker in other areas, but the epidermis as a whole was still thinner than in the control. 
The connective tissue of the dermis also regained some of its pre- exposure appearance with regrowth of few of the epidermal appendages (HF

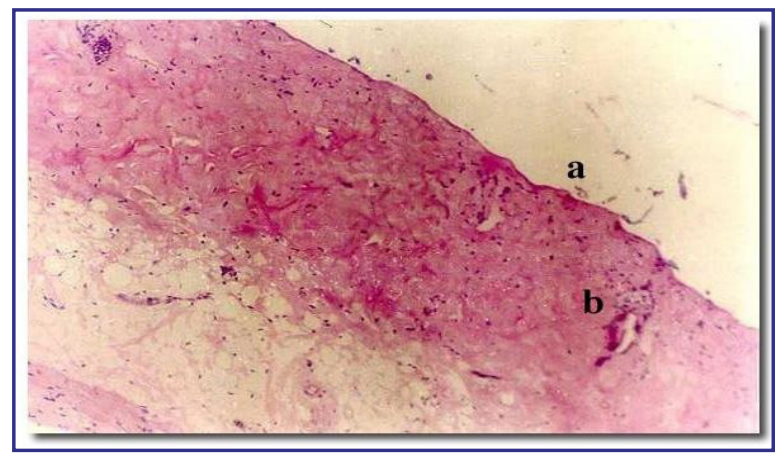

Fig. (6): Light micrograph of a section in the skin of a mouse in Group 3.1 showing:

a: total loss of the epidermis.

b: dermal thickening by dense tissue with total loss of hair follicles.

(HE X100)
\& PS) mostly in the lower dermis while in upper dermis they were still lost. The dermis is normal in appearance and is composed of loose tissue (Fig. 7).

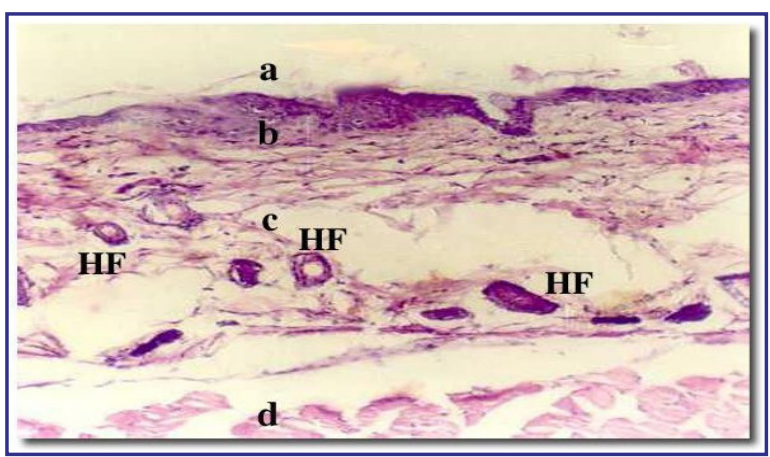

Fig. (7): Light micrograph of a section in the skin of a mouse in Group 3.1 \& 4.1 showing spontacous recovery a: stratum corneum b: granular layer c: dermis HF: hair follicles

(HE X100)

Table (1): Showing the HP changes in the skin of group 3.1 at different periods post whole body $\gamma$-irradiation.

\begin{tabular}{|c|c|c|c|c|c|c|}
\hline $\begin{array}{l}\text { Time interval } \\
\text { post IR }\end{array}$ & Epidermis & $\begin{array}{c}\text { Rete } \\
\text { ridges }\end{array}$ & Adenxa & $\begin{array}{c}\text { Dermal } \\
\text { thickening }\end{array}$ & $\begin{array}{c}\text { Blood } \\
\text { Telangectasis }\end{array}$ & $\begin{array}{c}\text { Vessels } \\
\text { Endarteritis }\end{array}$ \\
\hline $1^{\text {st }}$ day & $\begin{array}{c}* \text { total loss } \\
\text { (desquamation) }\end{array}$ & $\begin{array}{l}* * \\
\text { lost }\end{array}$ & $\begin{array}{c}\text { ** damaged Ps } \\
\text { units }\end{array}$ & $*$ & absent & absent \\
\hline $3^{\text {rd day }}$ & $\begin{array}{c}* * \\
\text { desquamation }\end{array}$ & $\begin{array}{l}* * \\
\text { lost }\end{array}$ & $\begin{array}{c}\text { ** damaged Ps } \\
\text { units }\end{array}$ & $*$ & $*$ & $*$ \\
\hline $8^{\text {th }}$ day & $\begin{array}{c}* * * \\
\text { desquamation }\end{array}$ & $\begin{array}{l}* * * \\
\text { lost }\end{array}$ & $\begin{array}{l}\text { *** Remenants of } \\
\text { Ps units }\end{array}$ & $* *$ & $* *$ & $* *$ \\
\hline $\begin{array}{l}\text { During the } \\
2^{\text {nd }} \text { week }\end{array}$ & $\begin{array}{c}* * * \\
\text { desquamation }\end{array}$ & $\begin{array}{l}* * * \\
\text { lost }\end{array}$ & $\begin{array}{c}* * \text { total loss of } \\
\text { HFs }\end{array}$ & $* * *$ & $* *$ & $* *$ \\
\hline $\begin{array}{l}\text { During } \\
\text { the } 3^{\text {rd }} \text { week }\end{array}$ & $\begin{array}{c}* * \\
\text { atrophy } \\
\text { (thinning) }\end{array}$ & $\begin{array}{l}* * \\
\text { flat }\end{array}$ & $\begin{array}{l}\text { * loss of HFs } \\
\text { and Ps units in } \\
\text { upper dermis with } \\
\text { growing HFs in } \\
\text { lower dermis }\end{array}$ & $*$ & variable & Variable \\
\hline $\begin{array}{c}\text { During } \\
\text { the } 4^{\text {th }} \text { week }\end{array}$ & $\begin{array}{c}* \\
\text { atrophy } \\
\text { (thinning) }\end{array}$ & $\begin{array}{c}* * \\
\text { small }\end{array}$ & $\begin{array}{l}\text { ** Growing HFs } \\
\text { and Ps units in the } \\
\text { whole dermis }\end{array}$ & - & variable & variable \\
\hline
\end{tabular}

N : Normal

*: Mild
Ps :Pilosebaceous units

**: moderate
HFs : Hair follicle

*** : severe

\section{Group (3.2): (Shot-laser group):}

H.P examination of skin biopsies carried out during the first 7 days revealed insignificant regenerative changes.
On the $8^{\text {th }}$ day of He-Ne irradiation (4 episodes):

The biostimulatory effect of He-Ne laser on the keratinocytes was evident by regeneration of the epidermis to approximate the pre-exposure thickness in 
some areas while in others, epidermal thinning was still evident. Re-growth of the basal layer was nearly complete but rete ridges were still not fully developed. The dermis regained its normal appearance and was seen to be formed of loose connective tissue. Loss of hair follicles was confined to the upper dermis with large number of proliferating hair follicles in lower dermis (Fig. 8).

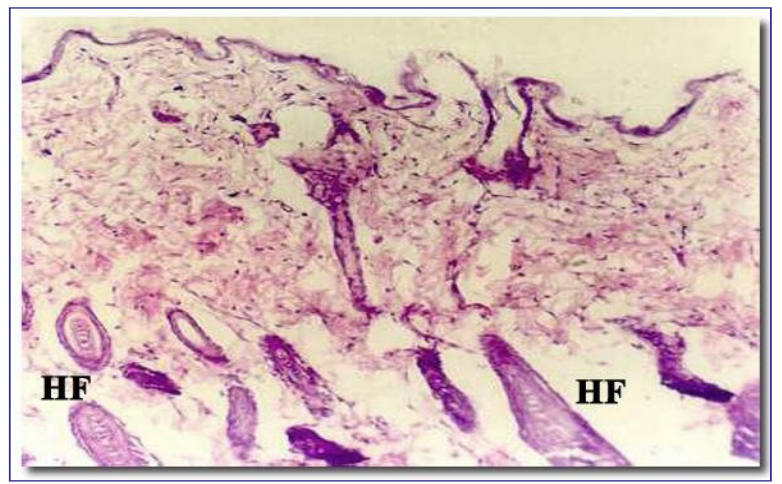

Fig. (8): Light micrograph of a section in the skin of a mouse in Group 3.2 showing early treatment with $\mathrm{HeNe}$ laser.

(HE X250)

At the end of the Second week of starting treatment (7 episods):

Evidence of regenerative activities included presence of well formed, complete epidermis with well developed rete ridges and the presence of many proliferating hair follicles scattered all over the whole dermis, reaching deep to the subcutaneous layer (Fig. 9).

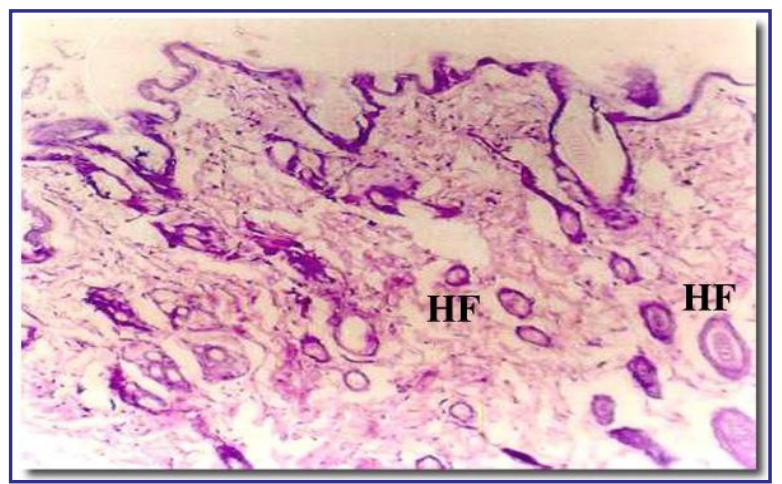

Fig. (9): Light micrograph of a section in the skin of a mouse in Group 3.2 showing complete treatment with $\mathrm{HeNe}$ laser. (HE X250)
Group (4.1): (Cumulative group) Table 2

One day post irradiation up to the $8^{\text {th }}$ day:

Severe desquamation of epidermis was accompanied by complete loss of rete ridges. Hair follicle (HFs) and sebaceous glands were present but were markedly destroyed (Fig.10). Dermal thickening was mainly due to presence of severe dermal edema with dilated congested blood vessels (telangiectasia), as well as the appearance of dense pink ground material in the dermis similar to that observed in the shot group (Fig. 10).

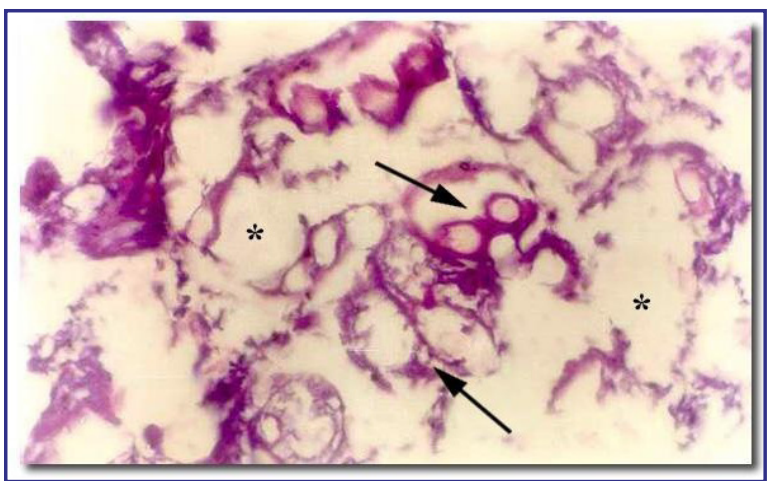

Fig. (10): Light micrograph of a section in the skin of a mouse in Group 4.1 showing:

a: many destroyed hair follicles (arrow).

b: dermal edema.

(HE X400)

During the second and the third week

The HP changes were nearly the same as those described previously with some decrease in the amount of dermal edema fluid in the dermis associated with an increased dermal thickening. The new pathological changes that developed during this period were epidermal atrophic (thinning) with flat rete ridges, in addition to complete loss of HFs.

During the fourth week:

The HP picture was suggestive spontaneous healing after cumulative irradiation was quite similar to those observed with the animals that had received the shot dose radiation. The stratum corneum and granular layer showed re-growth and regained normal thickness in some areas, becoming even thicker in other areas but the epidermis as a whole thinned. 
The epidermal appendages showed proliferation in dermis they were still lost. the lower dermis in the lower dermis while in upper

Table (2): Showing the HP changes in the skin of group 4.1 at different periods post whole body $\gamma$-irradiation.

\begin{tabular}{|c|c|c|c|c|c|c|}
\hline $\begin{array}{c}\text { Time interval } \\
\text { post IR }\end{array}$ & Epidermis & $\begin{array}{l}\text { Rete } \\
\text { ridges }\end{array}$ & Adenxa & $\begin{array}{c}\text { Dermal } \\
\text { thickening }\end{array}$ & $\begin{array}{c}\text { Blood } \\
\text { Telangectasis }\end{array}$ & $\begin{array}{c}\text { Vessels } \\
\text { Endarteritis }\end{array}$ \\
\hline $1^{\text {st }}$ day & $\begin{array}{c}* * * \\
\text { total loss } \\
\text { (desquamation) }\end{array}$ & $\begin{array}{l}* * * \\
\text { lost }\end{array}$ & $\begin{array}{c}\text { ** HFs and Ps } \\
\text { glands present but } \\
\text { destroyed }\end{array}$ & $\begin{array}{l}* * * \text { edema } \\
* \text { dense } \\
\text { diffuse } \\
\text { thickening }\end{array}$ & $* *$ & $* *$ \\
\hline $3^{\text {rd day }}$ & $\begin{array}{c}* * * \\
\text { total loss } \\
\text { (desquamation) }\end{array}$ & $\begin{array}{l}* * * \\
\text { lost }\end{array}$ & $\begin{array}{c}* * * \text { HFs and Ps } \\
\text { glands present but } \\
\text { destroyed }\end{array}$ & $\begin{array}{l}* * * \text { edema } \\
* * \text { dense } \\
\text { diffuse } \\
\text { thicjening }\end{array}$ & $* *$ & $* *$ \\
\hline $8^{\text {th }}$ day & $\begin{array}{c}* * * \\
\text { Total loss } \\
\text { (desquamation) }\end{array}$ & $\begin{array}{l}* * * \\
\text { lost }\end{array}$ & $\begin{array}{c}* * \text { Remnants of } \\
\text { destroyed Ps units }\end{array}$ & $\begin{array}{l}* * \text { edema } \\
* * \text { dense } \\
\text { diffuse } \\
\text { thickening }\end{array}$ & $* *$ & $* *$ \\
\hline $\begin{array}{l}\text { During the } \\
2^{\text {nd }} \text { week }\end{array}$ & $\begin{array}{c}* \\
\text { atrophy } \\
\text { (thinning) }\end{array}$ & $\begin{array}{c}* \\
\text { flat }\end{array}$ & * total loss of HFs & $\begin{array}{l}* \text { edema } \\
* * * \text { dense } \\
\text { diffuse } \\
\text { thickening }\end{array}$ & $* *$ & $* *$ \\
\hline $\begin{array}{l}\text { During the } \\
3^{\text {rd }} \text { week }\end{array}$ & $\begin{array}{c}* * \\
\text { atrophy } \\
\text { (thinning) }\end{array}$ & $\begin{array}{l}* * \\
\text { flat }\end{array}$ & $\begin{array}{c}* \text { Total loss of } \\
\text { HFs }\end{array}$ & $\begin{array}{l}* * * \text { dense } \\
\text { diffuse } \\
\text { thickening }\end{array}$ & $* * *$ & $* * *$ \\
\hline $\begin{array}{l}\text { During the } \\
4^{\text {th }} \text { week }\end{array}$ & $\begin{array}{c}* \\
\text { atrophy } \\
\text { (thinning) }\end{array}$ & $\begin{array}{c}* * \\
\text { small }\end{array}$ & $\begin{array}{l}\text { * loss of HFs } \\
\text { and Ps units in } \\
\text { upper dermis with } \\
\text { growing HFs in } \\
\text { lower dirmis }\end{array}$ & $\begin{array}{c}* \text { dense } \\
\text { diffuse } \\
\text { thickening }\end{array}$ & $* *$ & $* *$ \\
\hline
\end{tabular}

HFs : Hair follicle

* : Mild

Ps :Pilosebaceous units

**: moderate

\section{Group (4.2): (Cumulative-laser group):}

On the $8^{\text {th }}$ day of He-Ne irradiation (4 episodes):

Partial re-growth of the epidermis was associated with partial reappearance of the rete ridges and proliferating basal cells (Fig 11). Although hair follicles were still lost in the upper dermis, yet in the lower dermis crowding of hair follicles was very

$$
\text { *** : severe }
$$

evident. Some hair follicles were also seen encroaching on the subcutaneous layer (Fig 12). The dermis showed increased fibroblastic reaction, leukocytic infiltration and neovascularization. Meanwhile, the dense diffuse thickening of the dermis caused by IR exposure appeared to have a patchy distribution (Fig 11). 


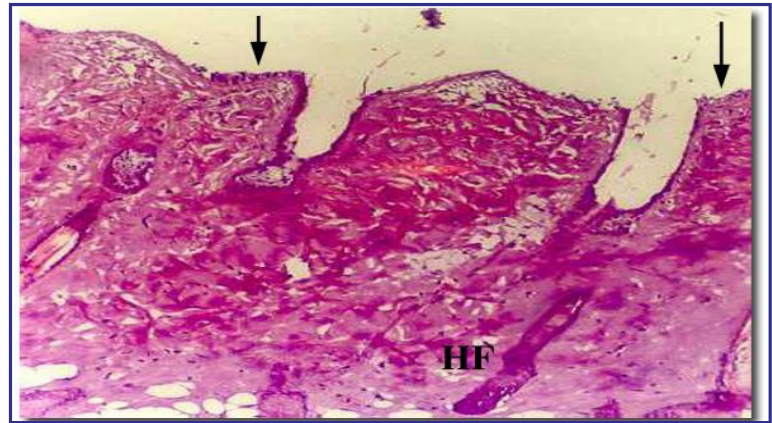

Fig. (11): Light micrograph of a section in the skin of a mouse in Group 4.2 showing early treatment with $\mathrm{HeNe}$ laser (arrow) pointing at partial regrowth of the epidermis. (HE X100)

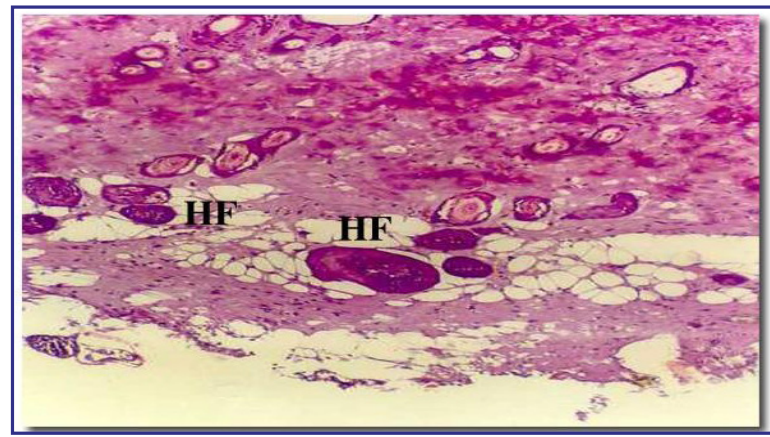

Fig. (12): Light micrograph of a section in the skin of a mouse in Group 4.2 showing.

Crowding of the hair follicles in upper and lower dermis. Growing hair follicles (HF) are also seen in the subcutaneous layer.

(HE X250)

At the end of the second week of starting treatment:

Evidence of regenerative activities were the same as observed in the shot group and included the presence of a well formed complete epidermis with preserved rete ridge and the presence of many proliferating hair follicles scattered throughout the whole dermis (Fig. 13).

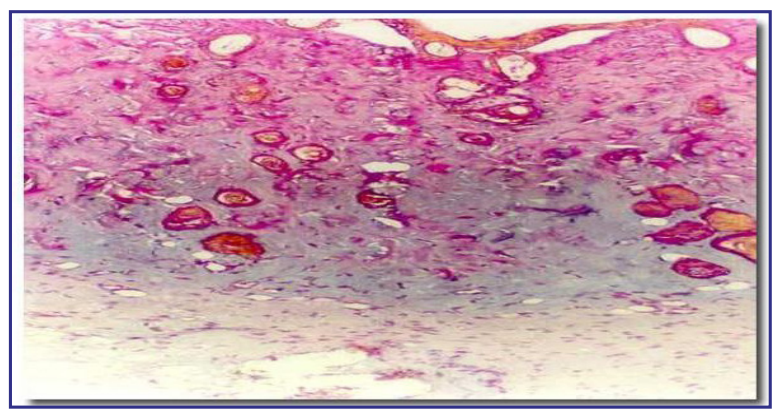

Fig. (13): Light micrograph of a section in the skin of a mouse in Group 4.2 showing collagen in deep dermis (green) and other ground substance material in upper dermis. (HE X100)
Yet, in the cumulative-laser group the dermis did not regain its normal pre exposure thickness or appearance and with time the dense diffuse pink thickening changed into greenish pink (Fig. 13), then turned into green (Fig. 14). This dense collagenous dermis (green) as well as many crowding growing hair follicles in the dermis and subcutaneous tissue (red) remained up to the end of the experimental period (Fig. 14\&15).

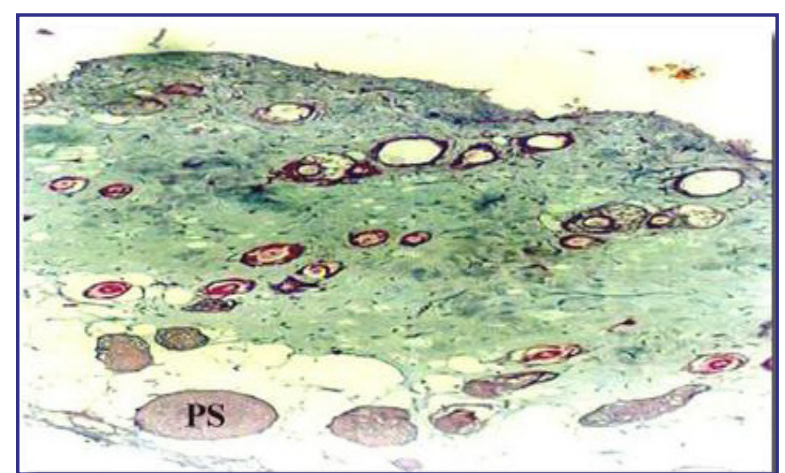

Fig. (14): Light micrograph of a section in the skin of a mouse in Group 4.2 showing dermal collagenous thickening and scattered pilosebaceous units. (HE X250)

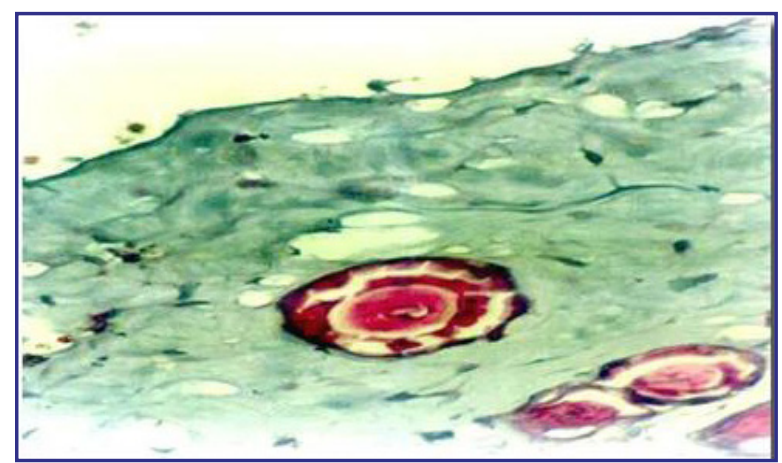

Fig. (15): Light micrograph of a section in the skin of a mouse in Group 4.2 showing dense collagenous dermis (green) with growing hair follicles (red) representing regenerative activity.

(HE X250)

\section{DISCUSSION}

The effect of the laser radiation on living tissue, known as photobiomodulation, has been increasingly used with the purpose of improving the quality of wound healing (Farivar, 2014). He-Ne laser is the most common and inexpensive gas laser used for photo modulation. It penetrates as deep as $0.5 \mathrm{~mm}$ into freshly excised human skin which is regarded 
as sufficient for the induction of wound healing because most of the relevant target cells of low level laser irradiation are located within the epidermis and upper dermis (Hawkins et al., 2005). El-Batanouny (2009) used He-Ne laser therapy at thewavelength of $632.8 \mathrm{~nm}$ for enhancing healing of chronic leg ulcers. In the current study, He-Ne laser was used with the fluence of $5 \mathrm{~J} / \mathrm{cm}^{2}$ and wave length 632.8 to stimulate and/or accelerate the reparative process in the skin after whole body $\gamma$ - irradiation (WB $\gamma \mathrm{I})$. During the present study laser irradiation was applied on alternative days. Ng et al. (2004) found that the multiple application treatment program of laser on alternate days seem to be more effective compared to either using a single treatment or in successive days. On the other hand, Andrade et al. (2014) documented that with the use of equal daily doses of $5 \mathrm{~J} / \mathrm{cm}^{2}$ better wound healing can be achieved. In a systemic review done by de Lima et al. (2016) addressing experiments on skin wounds in rats using LLL. It was perceived that a protocol does not exist in view of a wide variation in the use of power ( 9 to $500 \mathrm{~mW}$ ) and fluency $\left(1 \mathrm{to} 60 \mathrm{~J} / \mathrm{cm}^{2}\right)$; however, between the different wavelengths, the highlight was the combined use of red and infrared wavelengths showing better results than when used alone.

Starting from the first day of the present study, both the shot and cumulative $\gamma$-irradiated animals showed total loss of the epidermis which was accompanied with complete loss of rete ridges (extensive skin desquamation) (Fig. 4\&5). These findings are in accordance with those reported by Wong et al. (2013) who stated that IR is mostly absorbed by the epidermal layers with resultant damage of the epidermal keratinocytes. They added that the reaction of the epidermis to radiation exposure is the most extensively documented amongst all tissues.

Radio-sensitivity is highest in cells which are highly mitotic or undifferentiated. The cells most at risk are the basal cells of the epidermis; these are gradually lost after irradiation leading to the devel- opment of epidermal hypoplasia. Severe hypoplasia was identified as moist desquamation (Goodman, 2010).

Data of the present study as regards to moist desquamation of the skin where the epidermis was lost with accompanying dermal edema in the Cumulative $\gamma$-irradiated group (Fig. 10) is justifiable with that observed by Rezvani $\boldsymbol{e t}$ al. (2002) who reported the development of moist desquamation in rats as a result of whole body $\gamma$-irradiation (WBI) with graded sub lethal doses of $\gamma$-rays.

In the present study, pathologic changes induced by exposure of mice to yirradiation was evident in the shot $\gamma$-irradiated group in the form of severe desquamation, loss of rete ridges sebaceous glands and hair follicles as well as the presence of dense diffuse dermal thickening due to edema (Fig. 4,5).

Wynn and Vannella (2016) stated that Chronic inflammation is a lengthy process, in which active inflammation, tissue destruction, and attempts at healing occur in a simultaneous manner and is characterized by the infiltration of mononuclear inflammatory cells, tissue destruction, and attempts at healing by fibrosis and angiogenesis.

It is worth mentioning to indicate that the inflammation and tissue destruction in the present experiment was more pronounced in the cumulative- $\gamma$ irradiated mice (Fig. 10). Our results are in accordance with those of Kinoshita et al. (2016) who came into conclusion that skin exposure to IR in fractionating mode has strong damaging effect compared to those produced by the same dose if given in a single shot.

Destruction of the pilosebaceous unites in both IR groups included in the present study was evident from the day one. (Fig. 4\&5) in the shot group and in the commutative group as well (Fig. 9). Poeggeler et al. (2010) came to the conclusion that the hair follicle is highly sensitive to IR-induced skin damage due to its rapidly proliferating matrix keratinocytes. 
Resolution of the pathologic changes in the dermis of the shot $\gamma$-irradiated group under the influence of $\mathrm{He}-\mathrm{Ne}$ irradiation resulted in its regaining of its normal thickness in the form of non-oedematous connective tissue with newly formed vessels (Fig. 8\&9). As regard to the cumulative-laser group, laser therapy stimulated the deposition of dense collagenous infiltration, neovascularisation, besides enhancing the organization of collagen fibres and increasing the number of newly formed vessels. The observations strongly indicate that He-Ne LL therapy is efficient in accelerating the skin healing process probably by modulating the inflammatory phase and inducing collagen synthesis.

Our results are in accordance with those of Melo et al. (2011) who documented that LLL enhanced healing of surgical wounds by increasing deposition of collagen fibres' and increasing the number of newly formed vessels.

Several mechanisms were suggested to explain the anti-inflammatory effect of LLL. Piva et al. (2011) documented that reduction in the inflammatory process by LLL is through modulating inflammatory mediators (IL-1b, IL-6) and inflammatory cells (macrophages and neutrophils).The anti-inflammatory role of near- infrared light-emitting diodes was justified by Ibe et al. (2015).

Another important feature of the current study was that the use of LL He-Ne laser resulted in a regrowth of the damaged hair follicle as evidenced by the presence of many hair follicles scattering throughout the whole dermis.This type of laser was as well, able to stimulate hair growth in the deep subcutaneous layer which is normally devoid of hair follicle (in the shot-laser group Fig. 7\&8) \& (Fig. 9 in the commutative-laser group).

LLLT has been demonstrated to promote hair growth in androgenic alopecia in human (Lanzafame et al., 2014). In addition, experimental studies have shown that LLLT stimulated hair growth in mice subjected to chemotherapy-induced alopecia (Avram, 2007\&2009; Ommed, 2018 \& Manab, 2018). Wu et al. (2015) stated that to avoid side effects of hair follicle injury and scarring, appropriate combination of beam energy and density is required in the chosen laser.

The data of the present study highlighted the importance of LLL therapy as an efficient mean of accelerating the skin regeneration particularly after WBI. It highlights the potential therapeutic value of low level He-Ne laser in stimulating hair growth in the dermis after near total destruction of skin appendages as well as in deep subcutaneous tissue.

\section{REFERENCES}

- $\quad$ Alves, A.N.; Fernandes, K.P.; Deana, A.M.; Bussadori, S.K. and Mesquita-Ferrari, R.A. (2014): Effects of low-level laser therapy on skeletal muscle repair: a systematic review. Am. J. Phys. Med. Rehabil., 93(12): 1073.

- Andrade, F.; Clark, R.M. and Ferreira, M.L. (2014): Effects of low-level laser therapy on wound healing. Rev. Col. Bras. Cir., 41(2): 129.

- Avram, M.R. and Rogers, N.E. (2009): The use of low level light for hair growth (Part 1). J. Cosmet. Laser Ther., 11(2): 110.

- Avram, M.R.; Leonar, R.T.; Epstein, J.S.; Williiams, J.L. and Bauma, A.J. (2007): The current role of laser / light sources in the treatment of male and female pattern hairlos. J. Cosmet. Laser Ther., 9(1): 27.

- Bancroft, J.D. and Gamble, M. (2002): Bancroft's Theory and Practise of Histolofgical Techniques $5^{\text {th }}$ edition. Churchill Livingstone. London, New York \& Sydney.

- Chaves, M.E.; de Araújo, A.R.; Piancastelli, A.C. and Marcos, P.M. (2014): Effects of low-power light therapy on wound healing: LASER x LED. An Bras Dermatol., 89(4): 616.

- $\quad$ Chung, H.; Dai, T.; Sharma, S.K.; Huang, Y.; Carroll, J.D. and Hamblin, M.R. (2012): The nuts and 
bolts of low-level laser (light) therapy. Ann. Biomed. Eng., 40(2): 516.

- Di Lima, F.J.; de Oliveriam Neto, O.B.; Barbosa, F.T.; do Nascimento-Galvao, A.M.; Ramos, F.W., de Lima, C.C. and de Sousa Rodriues, C.F. (2016): Is there a protocol in experimental skin wounds in rats using low - level diode lase therapy (LLDLT) combining or not red and infrared wave lengths?. Laser Med. Sci., 31(4): 779.

- El Batanouny, M. (2009): Low level laser therapy for wound healing: Clinical and Biochemical assessments. Laser in medicine science and Practice in medicine Surgery, Dentistry and Veterinary, Ed. Z. Simunovic, pp 722-741.

- El Batanouny M.H.; Yousri, R.M.; Mahfouz, S. and Salem E.S. (2019): Role of low level laser in ameliorating the damaging effects of gamma irradiation on mice liver. Int. J. Radiat. Res., 17(1): 97.

- Farivar, S. (2014): Biological effects of low level laser therapy. J. Lassers Med., 5(2): 58.

- Goodman, T.R. (2010): Ionizing Radiation Effects and Their Risk to Humans Yale University School of Medicine, New Haven, CT; American College of Radiology

- Hawkins, D.; Houreld, N. and Abrahamse, H. (2005): Low level laser therapy (LLLT) as an effective therapeutic modality for delayed wound healing. Ann. N.Y. Acad Sci., 1056: 486.

- Hengel, S.M.; Aldrich, J.T.; Waters, K.M. and Stenoien, D.L. (2014): Quantitative Proteomic Profiling of Low-Dose Ionizing Radiation Effects in a Human Skin Model. Proteomes, 2(3): 382.

- Ibe, O.; Morency, E.E.; Sosa, P.; Burkow-Heikkinen, L. (2015): The role of near- infrared light-emitting diodes in aging adults related to inflammation. Healthy Aging Res., 4: 24.

- Isoir, M.; Buard, V.; Gasser, P.; Lati. E. and Benederitter, M. (2005): Human keratinocyte radioactivity is linked to redox modulation. J. Dermatol. Sci., 41(1): 55.
- Kinoshita, K.; Ishimine, H.; Shiraishi, K.; Kato, H.; Doi, K.; Kuno, S.; Kanayama, K.; Mineda, K.; Mashiko, T.; Feng, J.; Nakagawa, K.; Kurisaki, A.; Itami, S. and Yoshimura, K. (2014): Cell and Tissue Damage after Skin Exposure to Ionizing Radiation: Short- and Long-Term Effects after a Single and Fractional Doses. Cells Tissues Organs, 200(3-4): 240.

- Lanzafame, R.J.; Blanche, R.R.; Chiacchierini, R.P.; Kazmirek, E.R. and Sklar, J.A. (2014): The growth of human scalp hair in females using visible red light laser and LED sources. Lasers Surg. Med., 46(8): 601.

- Melo, V.A.; Anjos, D.C.; Albuquerque Júnior, R.; Melo, D.B. and Carvalho, F.U. (2011): Effect of low level laser on sutured wound healing in rats. Acta Cir. Bras., 26(2): 129.

- Merrifield, M.; Kovalchuk, O. (2013): Epigenetics in radiation biology: a new research frontier. Front Genet.; 4: 4(40).

- Ng, G.Y.; Fung, D.T.; Leung, M.C. and Guo, X. (2004): Comparison of single and multiple applications of GaAlAs Laser on rat medial collateral Ligament repair. Lasers Surg. Med.; 34(3): 285.

- Piva, J.A.; Abreu, E.M; Silva,V. And Nicolau, R.A (2011): Effect of low-level laser therapy on the initial stages of tissue repair: basic principles. An. Bras. Dermatol.; 86(5): 947.

- Poeggeler, B.; Bodó, E.; Nadrowitz, R.; Dunst, J. and Paus, R. (2010): A simple assay for the study of human hair follicle damage induced by ionizing irradiation. Exp. Dermatol.; 19(8): e306.

- Rashidi, S.; Yadollahpour, A. and Mirzaiyan, M. (2015): Considerations. Biomed. Pharmacol. J.; 8(2): 1121.

- Rezvani, M.; Rass, G.A. and Wikinson, J.M. (2002): Evidence for humoral effect on radiation response of rat foot skin. Br. J. Radiol.; 75(889): 50.

- Singh, M.; Alavi, A.; Wong, R. and Akita, S. (2016): Radiodermatitis: A Review of Our Current Understanding. Am. J. ClinDermatol.; 17(3):277. 
- Wong, S.; Han HorChor, H.H.; Moorthy, S.; Ong, C.T.; Phan, T.T.; Lu, J.J. (2013): Human epidermal keratinocytes death and expression ofprotein markers of apoptosis after ionizing radiation exposure. Int. J. Cancer Ther. Oncol.; 1(2): 0102.

- Wu, P.S.; Fan, S.M.; Chiu, H.Y.; Tsai, T.H. and Lin, S.J. (2015): Enhancing hair follicle regeneration by nonablative fractional laser: Assessment of irradiation parameters and tissue response. Lasers Surg Med.; 47(4): 331.

- Wynn, T.A. and Vannella, K.M. (2016): Macrophages in Tissue Repair, Regeneration, and Fibrosis. Immunity; 44(3): 450. 